\title{
30 anos de Educação \& Sociedade
}

7 pretensão da ciência de arrefecer o cansaço humano, tanto físico quanto mental, foi magistralmente exposta na famosa peça

de Brecht intitulada $A$ vida de Galileu. O inconformismo do cientista italiano diante da justificativa religiosa da inevitável reprodução da miserabilidade humana, que seria compensada pelas futuras benesses divinas, já portava consigo a esperança de que o emprego racional da técnica permitiria afirmar a realização de uma existência humana mais digna. Compreender a tecnologia como o conjunto de meios técnicos utilizados não só para a autopreservação, como também para a melhoria da espécie humana, significou confiar na concretização da promessa de que hoje já teríamos as condiçóes técnicas para amainar o sofrimento humano nas suas mais variadas formas de manifestação. Mas estamos muito distantes disso, principalmente porque a atual forma de reprodução das relações de produção necessita cada vez mais do acirramento das desigualdades sociais, com vistas de que seja gerado o capital necessário para o aprimoramento do próprio aparato tecnológico, entre outras coisas.

A atual fetichização da tecnologia se fundamenta exatamente no afastamento de tal promessa de felicidade, uma vez que esta finalidade primeva - a diminuição do cansaço humano - cede espaço no consciente, e até mesmo no inconsciente, para a consideração da tecnologia como algo em si, como se tivesse vida própria e assim se tornasse sujeito das ações humanas. Mas tal fato ocorre numa determinada situação histórica, ou melhor, na sociedade na qual a tecnologia adquire cada vez mais a condição de modus vivendi, ao invés de ser "apenas" um modus operandi. Muito mais do que uma simples soma de novas técnicas, a tecnologia adquire o status de modo de produção, a ponto de ser capaz de redimensionar tanto a esfera objetiva quanto a subjetiva. Há muito que o automóvel não pode ser mais definido exclusivamente como um meio de transporte, pois os proprietários que propagandeiam seu amor por tais máquinas são representantes de um espírito de um tempo, de uma cultura cujos membros são estimulados a deslocar sua 
libido preferencialmente para objetos e não para pessoas. Ao procederem dessa forma, expõem publicamente o anseio de poder mimetizar os atributos do carro, tais como força, potência e velocidade. E, assim, corroboram, concomitantemente, sua condição de objeto.

De fato, torna-se cada vez mais difícil discernir os limites entre os usos racional e/ou patológico dos meios técnicos. Nas pessoas que se tornam cada vez mais tecnologizadas, o uso racional dos e-mails, os atuais ícones da comunicação secundária, muitas vezes não se diferencia do comportamento compulsivo de conferir várias vezes durante o dia e a noite se há novas mensagens em nossas caixas eletrônicas, como se as mensagens fossem capazes de revidar nossos olhares e, ao mesmo tempo, asseverassem a impossibilidade de deixarmos de conferi-las em vários momentos de nosso cotidiano. Ao criar, organizar e reproduzir relaçóes sociais, a tecnologia redefine de forma mais intensa e decisiva as idiossincrasias de nossas identidades particular e coletiva, de tal modo que se faz cada vez mais necessária a reflexão crítica concernente a tal processo.

No que diz respeito à relação estabelecida entre educação e tecnologia, há uma miríade de temas candentes cujas características se metamorfoseiam numa velocidade já não tão desigual quando as comparamos com o ritmo vertiginoso de desenvolvimento tecnológico. As transformaçōes decorrentes da mediação das atuais forças produtivas espelhadas pelas novas tecnologias -, na relação entre educação e comunicação, determinam a ressignificação dos conceitos de infância, juventude, da formação de professores, da inclusão e/ou exclusão social, entre outros. As denominadas tecnologias de informação e comunicação (TIC) representam, atualmente, por assim dizer, a menina dos olhos dos educadores que visualizam a obtenção de possíveis benefícios nos processos educativos decorrentes do uso de tais TIC. Diante desse escopo, talvez nada seja mais representativo do que a defesa de políticas públicas voltadas para a realização da chamada educação superior a distância. O projeto da Universidade Aberta do Brasil (UAB), engendrado em 2005 pelo Ministério da Educação, expôs, como seu principal objetivo, articular e integrar: "o sistema nacional de educação superior a distância, em caráter experimental, visando sistematizar as açōes, programas, projetos, atividades pertencentes às políticas públicas voltadas para a ampliação e interiorização da oferta do ensino superior gratuito e de qualidade no Brasil".

De lá para cá, pululam, em número cada vez maior, as instituições públicas e privadas que ofertam vários cursos de ensino superior a 
distância, com o aval do governo brasileiro que considera, de forma geral, tal política educacional como uma importante alternativa para viabilizar a formação universitária de $30 \%$ dos estudantes brasileiros até 2011. Entre tentativas muitas vezes marcadas por atitudes açodadas, as quais se notabilizam pela aplicação de tal procedimento educativo a distância sem sequer mencionarem a palavra projeto pedagógico, nota-se o recrudescimento das pesquisas sobre os elementos que vão se tornando mais presentes nos debates do cenário educacional, tais como os papéis dos professores e tutores nos processos de ensino e aprendizagem a distância.

Talvez a principal discussão se refira à polêmica entre os ensinos presencial e a distância. Se, por um lado, a relação presencial entre professores e alunos nunca foi, por si só, garantia de obtenção de excelentes resultados na formação educacional dos alunos, por outro lado, a ênfase desmedida na aplicação do aparato tecnológico dos cursos superiores realizados a distância pode revitalizar o fetiche tecnológico, só que numa nova roupagem, em comparação com o chamado tecnicismo pedagógico que vicejou durante o período da ditadura militar.

$\mathrm{O}$ reforço da dicotomia entre ensinos presencial e a distância ocorre na medida em que a comunicação primária, presencial, se submete à secundária, não presencial. A comunicação primária pode e deve ser estimulada pelos recursos tecnológicos da secundária, haja vista o fato de que a produção tecnológica ainda porta consigo a promessa de contribuir decisivamente para arrefecer o cansaço humano. Mas a comunicação primária jamais deve ser apartada do processo educacional/formativo, pois, caso contrário, novas distâncias serão tanto engendradas quanto dissimuladas pela ostentação descabida das escolas providas por computadores, internet, aparelhos de televisão etc. e desprovidas da qualificação formativa de seus agentes. Seguindo essa linha de raciocínio, não se pode prescindir de cuidados fundamentais na incorporação das TIC pela educação, os quais se refletem no processo de ensino-aprendizagem e interferem na elaboração de planos de ensino e na adequação da infra-estrutura, no acompanhamento e avaliação das açóes e programas pedagógicos e na formação de professores, visando à qualidade do processo e ao fortalecimento dos sistemas de ensino. Diante do conjunto das ressignificações que a utilização das TIC promove, torna-se, portanto, fundamental considerar a relação formação, informação e conhecimento e suas respectivas características na sociedade tecnológica atual, uma vez que examinar a diferença qualitativa entre tais elementos significa remeter a reflexão sobre novas metamorfoses do próprio significado do educar. 
Educação \& Sociedade, neste número especial comemorativo de seus 30 anos, traz sua contribuição para a necessária ampliação das análises e da produção de conhecimento sobre o uso pedagógico das TIC na educação, de tal modo que as chamadas "escolas do futuro" - palavra hoje tão em voga na sociedade da tecnologia, encarada como modus vivendi - tenham condiçóes efetivas de se concretizar e não permanecer na condição de escola do futuro do pretérito, ou seja, daquilo que poderia ter sido.

A Revista aderiu ao convite da SCIELO para participar de uma nova iniciativa. Seguindo tendência internacional na área de periódicos científicos, a Biblioteca Eletrônica disponibilizou, aos usuários registrados no portal, mais um recurso de interação. Trata-se da funcionalidade "comentários", que permitirá aos leitores comentar qualquer artigo publicado nas revistas disponíveis naquele sistema.

Educação \& Sociedade, aderindo a essa iniciativa, permitirá a seus leitores comentar os artigos publicados em qualquer edição disponível no portal. Para participar é necessário estar registrado no portal SCIELO. Ao consultar qualquer texto da revista, basta acessar o link "comentários", disponível na caixa de serviços do artigo, e postar seu comentário. Para mais informação, consulte o tutorial em:

<http://blog.scielo.br/videos/tutorial/comentarios/index.htm>

Participe! Envie-nos seus comentários! 